\title{
Accounting Information Systems: A View from the Public Eye
}

Rachelle Paige Miller, Staff Associate, Henry Peters, P.C., USA Esther Bunn, Stephen F. Austin State University, USA

Kelly Noe, Assistant Professor, Stephen F. Austin State University, USA

\begin{abstract}
In order to fully appreciate the potential impact accounting information systems have on the accounting profession, an understanding of what accounting encompasses is necessary. Over the years, accounting has evolved from what many would call a "checks and balance" system to a much more complex system involving complicated activities such as calculating taxes and garnishments, auditing financial statements and processing payroll to name a few. It would be reasonable to think that advanced technology such as accounting information systems would only enhance the production of these activities. However, like with any "game changers," there are always potential threats involved. The objective of this paper is to determine if accounting information systems have become so helpful, they in fact have begun to hinder business and decrease productivity. This paperdemonstrates that although a majority population of those surveyed felt accounting information systems have added credibility to the accounting profession, there is still a large population that remain neutral on the subject leaving doubt as to the advantages and purpose of accounting information systems.
\end{abstract}

Keywor ds: Accounting Information Systems; Productivity; Survey Of Accounting Information Systems

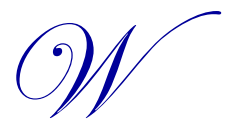

hat is accounting? Generically defined, accounting is the keeping of financial records. The general public that has not been exposed to accounting curriculum tend to believe accounting is simply adding and subtracting amounts from a beginning number to get an ending number, much like balancing a checkbook. However, any student that has been exposed to accounting curriculum will express that it is much more complicated than the simple adding and subtracting of numbers. Accounting encompasses a large scope of potentially complicating activities such as calculating taxes and garnishments, producing and distributing financial statements, auditing financial statements, and processing payroll. These tasks have become a part of the accounting profession through years of development of social and economic structures of countries and markets around the world. These developments have led the accounting profession to become more complicated. As the profession has evolved, so have the technological tools used to assist accountants in the profession. The use of technology in the accounting profession has led to the development of several accounting information systems software options. To better understand accounting information systems and the impact this technology has had on the accounting profession, it is important to take a brief look at the history of accounting.

According to Farag (2009), "the committee on Accounting History of the American Accounting Association... describe[s] accounting history as ... the study of evolution in accounting thought, practices, and institutions in response to changes in the environment and societal needs"(n.p.). Accounting, as it is currently known, only began to take shape in the fourteenth century; however, ancient Egyptians developed a system of basic accounting as early as 3200-3000 B.C. In Pharaonic Egypt, a new social organization arose, creating a need for some type of accounting structure. In this social structure, "the economic unit [tribal organization] taxed was not the individual but the village [as a whole]. The tax level on the villages was not arbitrarily assigned by the king and priests [,] [r]ather tax assessments and collectors (scribes) met with the village chief, who would as semble the village council, to negotiate the tax" (Farag, 2009, n.p.). As with any taxation unit, there was often surplus, and in the case of Pharaonic Egypt, the is sue of keeping track of "royal gifts" arose. To solve these is sues, "the economic surplus collected in the form of taxes was directed toward the priest who then redistributed some portion through the various levels of the bureaucracy, the temple artisans, and the workers who labored on the various religious and hydraulic projects" (Farag, 2009, n.p.). Additionally, because of the "complexity" of keeping track of goods collected in the form of royalgifts and tax surplus, 
"the development of an elaborate accounting system that recorded both assessments and payments and kept royal gifts separate from taxes" came about (Farag, 2009, n.p.). Though the accounting system may have been complex and elaborate of that day and age, it seems rudimentary in regards to modern-day accounting. In fact, "most accounting historians agree that ancient civilizations, such as Egypt developed bookkeeping as a sort of 'stores accounting' which merely provides an inventory of what property was available" (Farag, 2009, n.p.). The entire Egyptian accounting system is summarized in the literature review of a study by Yeboah et al (2014), titled Information Systems and Accounting Practices in Ghanaian Public Institutions. This study provides, "in ancient Egypt in the pharaoh's central finance department... scribes prepared records of receipts and disbursements of silver, corn and other commodit ies. One scribe recorded on papyrus the amount brought to the warehouse and another scribe checked the emptying containers on the roof as it was poured into the storage building. Audit was performed by a third scribe who compared these records" (Yeboa et al, 2014, p. 122). As previously stated, it was not until the $14^{\text {th }}$ century that accounting as it is known today began to form in European countries. The growth in maritime trade of Italian cities such as Florence and Venice resulted in a growing need for a more in-depth and encompassing accounting system and protocols (Yeboah et al, 2014). "Balance sheets were evident from around 1400 and the Medici family...had accounting records of "cloth manufactured and sold" (Yeboah et al, 2014, p. 122). In fact, most of the accounting terminology used in the profession (assets, liability, capital, and profit, to name a few) today finds roots in the Latin language (Yeboah et al, 2014). As a result of industrialization around the world, new organizational forms came about as the owners separated from the entities causing substantial changes in the accounting profession.

As the industrial revolution brought an industry focused economy rather than the agricultural focused economy previously in place, some form of checks and balances had to be put in place to keep large companies and corporations compliant with the public's wants and the economy's needs. The modern accounting profession filled these needs. As with all things in the world today, the accounting profession has been impacted by the technological world. As stated by Liu and Vasarhelyi (2014) "unfortunately, technology has often been used to simply automate existing manual processes and methodologies, instead of first restating problems and reengineering processes in light of new technologies and capabilities." Accounting information systems have been developed to assist accountants with the increased scope of the profession, brought about by developments in the world's social and economic fronts. There are several different types of systems available to companies large and small alike. Some of these systems are industry based, while others are more generic for small or multi-business use; however, all "computerized accounting systems enhance functionality of various accounting departments by increasing just in time accounting information. By enhancing timeliness of financial information, accountants can prepare reports and operations analys is that provides management an accurate view of current operations. The number of financial reports has been improved by computerized systems. Cash flow statements, market shares reports and departmental profit and loss are now more accessible with computerized systems. A prior observation shows a computerized accounting system has internal check and balance measures to ensure transactions and accounts are properly balanced before the financial statements are finally prepared. It also ensures that individual transactions are properly recorded in journal entries." (Yeboah et al, 2014, p. 124). Accounting information systems have revolutionized the accounting world by helping accountants provide more accurate information in an almost instant basis. Currently, if a business owner wants to track the balance sheet of the business, the owner is merely a few clicks of the mouse and strokes on the keyboard away from producing an instant look at his balance sheet, whereas prior to an accounting information system, the owner would have to wait for the information to be gathered and the statements be created. The mass amount of data collected to day, known as Big Data, is the result of ERP systems data gathering ability, this poses problems for accountants as well as auditors (Vasarhelyi et al 2015).

Liu and Vasarhelyi (2014) address the following 5 attributes of accounting:

1. Accounting is based on data: Has increasing data accessibility altered the accounting profession? How do accountants deal with data-related concerns such as security and privacy?

2. Accounting entails a substantive amount of information processing: Has the nature of data processing changed? If so, has it had feed forward effects on the profession?

3. Accounting is the field of business measurement: What has changed relative to this objective? Has the locus of measurement, have the variables to be measured, and/or has the frequency of measurement changed?

4. Accounting entails substantive data analysis: Have the new dat a analys is techniques affected accounting 
practice? Will the emerging analytical approaches modify the nature of accountants'work?

5. Accounting ultimately is delivered through reporting: How will information be delivered? Who will be the recipients? How will disseminated information be used?

The research done by Liu and Vasarhelyi (2014) exemplifies the issues created by automating the accounting information system. While accounting information systems have no doubt "changed the game" in many aspects of the accounting profession, the authors question if accounting information systems have become too helpful, to the point of hindering business and decreasing productivity. Many times with advanced technological tools used in professions across the world, the tools can become harmful to the business by allowing for corruption and theft of sensitive information and files. Vasarhelyi and Greenstein (2003) present this concept of electronization of business processes and the consequent deconstruction of the value chain. The readily available information has created an environment where hypersensitive information is now available to be knowingly or unknowingly sent to unauthorized users. The use of computerized accounting information systems can lead to files "[becoming] corrupted especially when money scandals are... detected" (Yeboah et al, 2014, p. 124). Yeboah et al (2014) performed a study to answer this question. In their study, they "selected and interviewed 40 employees of 30 public institutions in the Kumasi Metropolis [Gahana]" (p. 124). Upon reading the study, the authors decided to conduct a study similar in nature. Notable differences in the studies included length of study, selection of participants, participants' backgrounds and nationality. Methodology, results and discussion of the study are explained below.

\section{METHODOLOGY}

The survey was made available to the general populous via social media where participants were asked to take the survey anonymously. This distribution method was chosen to ensure a completely random selection of participants from varying age, gender, and educational, social and ethnic backgrounds. This will guarantee a nonbiased response to the survey. First, the survey asked participants to provide basic demographic information, including age and educational background. Next, participants were asked if the company they were as sociated with used an acco unting information system, and then the respondents were given the choice of commonly used accounting software (this question included an "other" option, with a space provided for participants to provide a response). Finally, participants were asked to record if they strongly agreed, agreed, felt neutral, disagreed or strongly disagreed with statements related to the accuracy and cost of information provided by accounting information systems.

\section{RESULTS}

The descriptive statistics of the survey respondents can be found in Table 1. The sample size is 46 . Related to age demographics, 20\% responded they were between 18 and 24, 21\% responded they were between 25 and 34 , 9\% responded they were between 35 and 44, 35\% responded they were between 45 and 54, 15\% responded they were between 55 and 64, and 0 participants were over the age of 65. Participants responded that $47 \%$ have a high school diploma or GED, $17.6 \%$ of participants have an as sociate degree, $17.6 \%$ have a bachelor degree, and $17.6 \%$ have a master degree. Within the sample, $56 \%$ of the companies that participants associated with used accounting information systemsoftware, $23 \%$ did not, and $21 \%$ of participants were unsure of the company's position on use of an accounting information system. The survey results can be found in Table 2. Based on all of the responses, $56 \%$ of the sample reported using accounting information software. Of this sample, 55.6\% used QuickBooks, $11.1 \%$ used Sage50 (formerly Peachtree), 11.1\% used Quicken, and 22.2\% replied "Other," where systems such as ADP, Alliant Systems, Frog, iLogic, Winteam, and TxEIS were reported as being used within the companies. When asked if participants felt that accounting information systems assisted in the timely delivery of financial statements, $2.56 \%$ strongly disagreed, $0 \%$ disagreed, $23.08 \%$ remained neutral, $41.03 \%$ agreed, and 33.33\% strongly agreed. When asked if participants felt that accounting information systems assisted in producing minimally erroneous or error-free financial statements, $2.56 \%$ strongly disagreed, 5.13\% disagreed, 25.64\% remained neutral, $46.15 \%$ agreed, and $20.51 \%$ strongly agreed. When asked if participants felt that accounting information systems aided in making financial statements readily available to parties in need, 2.63\% strongly disagreed, $2.63 \%$ disagreed, $23.68 \%$ remained neutral, $42.11 \%$ agreed, and $28.95 \%$ strongly agreed. When asked if participants felt that accounting information systems assisted in the reduction of employees needed for data entry/clerical work, $0 \%$ strongly disagreed, $7.69 \%$ disagreed, $38.46 \%$ remained neutral, $30.77 \%$ agreed, and $23.08 \%$ strongly agreed. When asked if participants felt that accounting 
information systems assisted in the reduction of costs associated with data entry/clerical work, $2.56 \%$ strongly disagreed, $5.13 \%$ disagreed, $30.77 \%$ remained neutral, $38.46 \%$ agreed, and $23.08 \%$ strongly agreed.

Table 1. Descriptive Statistics

$$
\mathrm{n}=46
$$

\begin{tabular}{l|c|l|l|l|l}
\hline \multicolumn{1}{c|}{ AGE } & $\begin{array}{c}\text { \% of } \\
\text { Respondents }\end{array}$ & \multicolumn{1}{|c|}{$\begin{array}{c}\text { Level of } \\
\text { Education }\end{array}$} & $\begin{array}{c}\text { \% of } \\
\text { Respondents }\end{array}$ & Use of AIS & $\begin{array}{c}\text { \% of } \\
\text { Respondents }\end{array}$ \\
\hline $18-24$ & 20 & High School or GED & 47.2 & Use AIS & 56 \\
\hline $25-34$ & 21 & Associate & 17.6 & Do not use AIS & 23 \\
\hline $35-44$ & 9 & Bachelor & 17.6 & Unsure of AIS use & 21 \\
\hline $45-54$ & 35 & Master & 17.6 & & \\
\hline $55-64$ & 15 & & & & \\
\hline 65 and up & 0 & & & & \\
\hline
\end{tabular}

Table 2. Survey Results

\begin{tabular}{l|c|c|c|c|c}
\hline & $\begin{array}{c}\text { Strongly } \\
\text { Disagree }\end{array}$ & Disagree & Neutral & Agree & $\begin{array}{c}\text { Strongly } \\
\text { Agree }\end{array}$ \\
\hline Timely Delivery & $2.56 \%$ & 0 & $23.08 \%$ & $41.03 \%$ & $33.33 \%$ \\
\hline Minimal/Free of error & $2.56 \%$ & $5.14 \%$ & $25.64 \%$ & $46.15 \%$ & $20.51 \%$ \\
\hline Readily Available & $2.63 \%$ & $2.63 \%$ & $23.68 \%$ & $42.11 \%$ & $28.95 \%$ \\
\hline Reduced Data Entry & 0 & $7.69 \%$ & $38.46 \%$ & $30.77 \%$ & $23.08 \%$ \\
\hline
\end{tabular}

\section{DISCUSSION}

The survey responses provide a glimpse into how the direct and indirect "non-accounting" users might view accounting information systems. While the majority of participants responded as expected (provide proof that accounting information systems is a helpful part of the accounting world), there were some unforeseen results as well. With all of the statements provided to participants, an unexpected number of participants were neutral on the questions provided. In every category, at least $23 \%$ of participants felt neutral about the subject matter. Participants are not agreeing with the statements. Some of these responses can be attributed to the participant's unawareness on the subject matter at hand; however, the results are still surprising in this aspect. Though the participants are not disagreeing with the statements, they are not agreeing with the statements provided either. From this it can be inferred that there is uncertainty on the authenticity and effectiveness of accounting information systems among the general public.

While approximately $74 \%$ of participants agreed or strongly agreed that accounting information systems help in the timely delivery of financial statements, and about $3 \%$ of participants dis agreed or strongly dis agreed, a surprising $23 \%$ felt neutral about the statement; a collective $26 \%$ of participants felt that the accounting information system have not helped with the timely delivery of financial statements. This is in contrast of the Yeboah et al (2014) study, which concluded that $95 \%$ of their study populous agreed or strongly agreed that information and communication technologies, which is another term for accounting information systems, helped in the timely delivery of financial statements. In line with this, $67 \%$ of respondents agreed or strongly agreed with the statement that accounting information systems helped deliver minimally erroneous/error-free financial statements, leaving an astonishing $26 \%$ that felt neutral and approximately $8 \%$ that actually disagreed (or strongly disagreed). In the study performed by Yeboah et al (2014), only $60 \%$ of participants agreed or strongly agreed that information communication technologies aided in the issuance of error free financial statements. More concurrent with what would be expected, $71 \%$ of participants agreed that accounting information systems as sist in helping to make financial statements readily available to users, but even still, $23 \%$ remained neutral and 6\% disagreed. In contrast, approximately $10 \%$ more $(80 \%$ of total responses) of the participants in the Yeboah et al (2014) study agreed or strongly agreed that information and communication technologies created an avenue to access financial information to users. Though accounting information systems live a short victory because when it comes to the cost associated with accounting information systems, only $62 \%$ of participants agreed that accounting information systems assisted in reducing the costs as sociated with data entry or clerical work, leaving $31 \%$ neutral and $8 \%$ to disagree. Even more surprising, only $54 \%$ of 
participants agreed (or strongly agreed) that accounting information systems help reduce the number of employees needed for data entry/clerical work, leaving 38\% neutral and $8 \%$ disagreeing. While there were several fact ors that could have contributed to the decline of approval of accounting information systems between 2014 and 2015 , a trend can be seen.

\section{CONCLUSION}

Finding that less than $75 \%$ of the sampled group agreed or strongly agreed to any one of the statements a sked should raise a red flag for the accounting profession and accounting information systems software developers and development companies. The discoveries made during the course of this study demonstrate that perhaps there should either be a change in the way that accounting information systems are presented, or there should be a movement to better inform the public of the advantages of accounting software and the purposes it serves in the accounting profession. "Passing the CPA exam is a priority for most accounting students regardless of their other aspirations. The exam's current limited AIS content therefore serves as a limitation on student demand for additional AIS content regardless of the relevance of such content to their careers" (unknown 2014). How will the technology used every day change in the foreseeable and unforeseeable future? Will there be a movement toward a better understanding of accounting information systems in the public eye? Will accounting begin to revert to a more pen and paper profession versus the technological movement it has recently faced?

\section{AUTHOR BIOGRAPHIES}

Rachelle Paige Miller is a Staff Associate with Henry Peters, P.C., 3310 S. Broadway, Suite 100, Tyler TX 75701 USA. E-mail: pmiller@henrypeters.com

Esther Bunn, MPA, CPA, CGMA is a Lecturer with the Gerald W. Schlief School of Accountancy at Stephen. F. Austin State University, P.O. Box 13005, SFA Station, Nacogdoches, TX 75962 USA. Her research areas include accounting education and financial accounting. She teaches in the areas of Intermediate Accounting, financial accounting, Managerial Accounting, Tax And Audit. E-mail: estherbunn@sfasu.edu

Kelly Noe, PhD, CPA, CGMA is an Assistant Professor with the Gerald W. Schlief School of Accountancy at Stephen F. Austin State University, P.O. Box 13005, SFA Station, Nacogdoches, TX 75962 USA. Her research areas include non-profit accounting concentrated in the healthcare industry, accounting information systems and financial accounting. She teaches in the areas of accounting information systems, intermediate accounting and graduate accounting research. E-mail: noekelly@sfasu.edu

\section{REFERENCES}

Unknown. 2014. "AIS as a Facilitator of Accounting Change: Technology, Practice, and Education." Editorial. American Accounting Association, Fall 2014:28(2):1-15.

Farag, S.M. 2009. The Accounting Profession in Egypt: Its Origin and Development. The International Journal of Accounting, doi:10.1016/j.intacc.2009.09.001.

Krahel, J.P. and M.A. Vasarhelyi. 2014. AIS as a Facilitator of Accounting Change: Technology, Practice, and Education. Journal of Information Systems, 28(2):1-15.

Liu, Q and M.A. Vasarhelyi. 2014. Big Questions in AIS Research: Measurement, Information Processing, Data Analy sis, and Reporting. Journal of Information Systems, 28(1):1-17.

Yeboah, E., K.O. Kwateng, and C. Oppong. 2014. Information Systems And Accounting Practices In Ghanaian Public Institutions. Accounting \& Taxation, 6(1):121-132.

Vasarhelyi, M.A., K. Alexander, and B. Tuttle. 2015. Big Data in Accounting: An Overview. Accounting Horizons, 29(2):381396.

Vasarhelyi, M and M. Greenstein. 2003. Underlying Principles of the Electronization of Business: A Research Agenda. International Journal of Accounting Information, 4(1):1-25. 


\section{NOTES}

